\title{
The use of multipurpose community telecentres and their services in Malawi: the case of Lupaso Community Telecentre
}

\author{
Sellina Khumbo Kapondera ${ }^{1}$ and Genevieve Hart ${ }^{2}$ \\ skapondera@gmail.com ORCID: orcid.org/0000-0001-6686-6788 \\ genevievehrt@gmail.com ORCID: orcid.org/0000-0002-3799-0998
}

\begin{abstract}
Received: 27 May 2016
Accepted: 10 July 2016

Telecentres aim to bridge digital divides between rural and urban communities. In many developing countries, like Malawi, the assumption is that once telecentres are established, people will adopt them. The purpose of the study was to examine the factors influencing the use of telecentres in rural areas of developing countries by means of a case study of Lupaso Community Telecentre, in a remote region of Malawi. Following the example of a study of public computing facilities in Cape Town (Chigona \& Licker 2008), the study employed Rogers' Diffusion of Innovation (DOI) theory as a theoretical frame. Data were gathered through a mix of methodologies: questionnaires, interviews, observation, and records analysis. The study reveals that a large majority of users view the telecentre as an empowering project and are satisfied with its services. They perceive it to be improving human skills, helping the economy and strengthening the social capital of the surrounding community. However, it seems that the telecentre benefits only a small percentage of the community. Access is uneven. One surprising finding is that the centre's Information and Communication Technologies (ICTs) are not the chief attraction. The factors that negatively impact on the use of the ICTs are lack of internet searching skills, frequent electricity blackouts, lack of local content, and fees charged. To fulfil their mission, it is recommended that telecentres in developing communities enhance their services with information literacy and literacy education programmes.
\end{abstract}

Keywords: Malawi, digital divide, telecentres, multipurpose community telecentres, Lupaso Telecentre, rural areas, public computing facilities

\section{Background}

This paper reports on a study that investigated factors that influence the use of telecentres in Malawi by means of a case study of the Lupaso Community Telecentre (henceforth, Lupaso Telecentre). A telecentre is "a physical space that provides public access to Information and Communication Technologies (ICTs) for educational, social and economic development" (Harris 2001: 73). Telecentres serve to bridge the digital divides between rural and urban communities (Isaacs 2007: 5).

Malawi is classified as a least-developed country and a highly-indebted country by the United Nations Development Program and the World Bank respectively. In 2015, Malawi was ranked 173 out of 187 countries on the Human Development Index (Human Development Report 2015: 210). Almost half of the country's population of approximately fifteen million people lives on less than $\$ 1$ a day (Malawi 2012: 204) and 83.9\% live in rural areas (Human Development Report 2015: 236). Rural areas are characterised by few roads and means of transport, inadequate access to ICTs like telephones and computers, low income levels, and high dependence on farming and fishing (Chigalu 2006, Isaacs 2007: 5). Literacy rates indicate disparities between rural and urban regions and between genders: $61 \%$ of rural dwellers are literate as compared to $89 \%$ of urban dwellers (Malawi 2012: 21 ) and $74 \%$ of males are literate compared with $70 \%$ of females (Human Development Report 2015: 244). Malawi's official language is English. However, it has a diversity of languages. The national and dominant language is Chichewa, but other prominent languages include Yao, Tumbuka, Nkhonde, Lomwe and Tonga (Department of Immigration Republic of Malawi n.d.).

Malawi's ICT infrastructure is poor. In 2014, only 5,590 people were broadband internet subscribers; 64,247 had access to fixed telephones; and 6,487,304 were mobile phone subscribers (Nyirenda 2014). There have been some notable initiatives by the Malawian government to bridge the digital divide since the early 2000s: first was the formulation of the Rural Telecommunications Policy in 2002 by which the government, in collaboration with telephone network service providers, acquired cheap cellular telephones to be sold to Malawians at a cheaper price (Chigalu 2006); second was the formulation of the Malawi Information and Communications Technology (ICT) Policy in 2003 aimed at improving ICT infrastructure in rural areas through the establishment of Multipurpose Community Centres (Malawi 2003); third was the development of the Malawi Growth Development Strategy 2006-2011, which has led to the establishment of rural information centres housing computers and information in various formats (Chigalu 2006). Telecentres in Malawi started

1. Sellina Khumbo Kapondera is a lecturer in the Department of Library and Information Science, Mzuzu University, Malawi

2. Genevieve Hart is Associate Professor (Extraordinary) in the Department of Library and Information Science, University of the Western Cape, South Africa 
to be established in 2007, under the auspices of the Malawi Communications Regulatory Authority (MACRA) with funding from the International Telecommunications Union ${ }^{3}$. The Government of Malawi is continuing to establish telecentres under the Connect a Constituency Project ('Malawi VP opens K80M multipurpose telecentre in Karonga' 2012). So far, seventyone telecentres have been set up; Lupaso is one of only three centres that is managed by the surrounding community.

The study of Lupaso Telecentre in Malawi relies on Rogers' Diffusion of Innovations (DOI) theory (1995), in common with several studies of telecentres in other countries such as India and South Africa (for example Roman 2003, Chigona \& Licker 2008). The term 'innovation' refers to a product that is perceived as new by the adopters but that is not necessarily new to all people (Mark \& Poltrock 2001: 232). According to the DOl theory, acceptance and spread of an innovation depends on the properties of the innovation, such as:

- $\quad$ perceptions of its relative advantages;

- $\quad$ how compatible it is with its potential users' circumstances;

- $\quad$ how difficult it is to use;

- $\quad$ how visible its benefits are;

- $\quad$ how the innovation is communicated (by mass media or by people talking to one another);

- $\quad$ who adopts it and when;

- $\quad$ the consequence of the innovation; and

- $\quad$ the surrounding social system (Rogers 1995, Roman 2003).

As Roman (2003:53) points out, telecentre projects should be evaluated while they are new so that adjustments can be made. It is hoped that lessons learned from this study will help telecentre managers and the Malawian Government understand ways of improving the social acceptability of telecentres.

\section{Models of public access to ICTs}

There exist different models of ICT public access venues. They include, for example, computer centres in public libraries, cybercafés, Thusong Service Centres, and telecentres. There is much overlap among these terms and models; all aim at bridging digital divides and contributing to socio-economic development. An investigation by the Human Sciences Research Council (HSRC) into ICT access across South Africa in 2007 concluded that public libraries have a wider spatial distribution than other information agencies like multipurpose community centres or telecentres and that their community orientation gives them an edge over the others (Tlabela et al. 2007: 101). Cybercafés target the better-off members of society and are more common in urban areas (Haseloff 2005). Thusong Service Centres are multipurpose information centres in remote regions of South Africa, through which the South African government provides access to government services and information (Government Communication and Information Systems 2013). Several now incorporate public libraries (Library and Information Services (LIS) Transformation Charter 2014: 53). In rural areas, telecentres are often the only venues for accessing ICT services (Gómez, Hunt \& Lamoureux 1999: 15, Haseloff 2005). Telecentres range from rooms with only basic ICTs to multipurpose information centres which serve also as public libraries.

\section{Brief literature review}

A perusal of the literature reveals the following themes: the relevance of telecentres to rural communities, usage patterns, the challenges facing telecentres and their users, and the factors influencing the diffusion of telecentres (Etta \& ParvynWamahiu 2003, Lesame 2006, Kumar \& Best 2007, Soriano 2007, Chilimo 2008, Chigona et al. 2011:1, Mtega \& Malekani 2009, Chikumba 2010, Abdulwahab \& Zulkhairi 2011).

Telecentres are relevant to their communities because they offer several benefits like improving human, financial, natural, physical and social capital by enabling users to connect and easily communicate (Parkinson \& Ramirez 2007, Soriano 2007, Chilimo 2008, Chigona et al. 2011: 12). Telecentres are also potentially important for fostering participative democracy and active citizenship at both local and national levels (Twinomurinzi, Phahlamohlaka \& Byrne 2012: 210). It seems that the majority of their users view them positively in their communities and are satisfied with the services that they provide (Lesame 2006, Etta \& Parvyn-Wamahiu 2003: xxiv).

Nonetheless, research indicates that these facilities are being underused and that they are not accessed equally by all groups of people in their communities. Mostly, the users tend to be male, young, school or college students, relatively more educated and belonging to higher-income households (Etta \& Parvyn-Wamihaiu 2003, Kumar \& Best 2007, Mtega \& Malekani 2009). In addition, though telecentres offer a wide range of services, studies show that some services are used more than others (Mtega \& Malekani 2009, Chikumba 2010)

The literature also shows that telecentres in rural regions in countries like India, Mexico and South Africa face a number of challenges and limitations. Some of these challenges include the unreliability and high cost of power supplies; the unreliability of telecommunications and the high cost of accessing them; inadequate physical facilities; and inadequate opening hours since many telecentres keep formal government working hours (Etta \& Parvyn-Wamihaiu 2003, Mtega \&

3. Banda, G. C. 2014. Personal communication, 10 May 2014 
Malekani 2009). Furthermore, Etta and Parvyn-Wamihaiu (2003) comment on weaknesses in telecentre management, especially evident in those owned by governments. For example, there are bureaucratic delays whenever telecentres management want to buy or fix equipment. Another challenge is the pressure to justify their existence in an age when some services, like the internet, may be accessed through mobile technologies (Chigona et al. 2011: 1). Telecentre users also grapple with their own challenges such as lack of internet searching or English language skills (Etta \& ParvynWamahiu 2003, Huerta \& Sandoval-Almazán 2007).

The literature reveals several factors that influence the success of telecentres, such as the complexity of the ICT equipment available in the telecentres, the bonds existing within communities, and the communication channels used to publicise the telecentres (Kumar \& Best 2007, Chigona \& Licker 2008, Abdulwahab \& Zulkhairi 2011). Of key importance is the compatibility of services with the needs, values and beliefs of community members (Kumar \& Best 2007, Chigona \& Licker 2008, Atwood et al. 2013). However, these studies show that factors influencing the use of telecentres in one community may not be the same as in another community. Therefore, as suggested by several writers such as Prado, Câmara \& Figueiredo (2011), it is important to conduct studies of the factors influencing the use of telecentres with respect to a given community.

\section{Research site: Lupaso Telecentre}

Lupaso Telecentre was chosen for the study because, having been operating since 2012, it should be relatively wellestablished but might still be regarded as an innovation. It is one of three so-called community managed centres in Malawi, under the Lupaso Telecentre Local Management Committee (LTLMC). As mentioned earlier, community orientation has been found to be a key factor in the success of public ICT facilities. The LTLMC is composed of representatives of various groups in the community including chiefs, teachers, youths and community organisations.

The main objectives of the telecentre, as laid out in its constitution, include:

- provision of communication facilities to the community to facilitate communication with people all over the world;

- establishment of a recreation centre to enhance proper utilisation of leisure time so as to minimise contraction of HIV/AIDS and other sexually transmitted diseases;

- $\quad$ the generation of funds for development projects for upliftment;

- creation of job opportunities; and

- $\quad$ acquisition of knowledge and technical skills in various disciplines.

Lupaso Telecentre is situated in the Mwambanya Village Traditional Authority of Kyungu, approximately twenty-two kilometres from Karonga Town in the north of Malawi. The total population of its catchment area is 7,880 , mostly Nkhonde-speaking. In the area there are twelve primary schools, two secondary schools, one health centre, two clinics providing health services to children below five years of age, four community-based organisations, and three youth groups ${ }^{4}$. The region has poor road networks and, in bad weather, the only means of transport are bicycles. The telecentre is one of two facilities providing public access to ICTs in the area. Nkhando Primary School, ten kilometres from Lupaso Telecentre, offers some ICT services for the community, although it has no internet connectivity. The school offers basic ICT skills training in a ten-day course. However, a visit to the school during this study found the computers unused and covered up. The nearest public library is Karonga National Library in Karonga Town.

Lupaso Telecentre has eight members of staff, recruited by the LTLMC together with MACRA, the government body responsible for telecentres ${ }^{5}$. Interviews in the course of the case study revealed that the telecentre is not as yet selfsustaining and MACRA continues to pay staff salaries. Lupaso Telecentre offers a wide range of ICT and office services all for a fee. Its library holds a collection of newspapers and pamphlets and it was supplied with books at its opening by the Malawi National Library Services and MACRA. But the library is not part of the national library network and does not have a regular supply of books. Over the case study period, the most popular space was the television room, where football is watched. Computer tutorials are offered to groups, in classes advertised every month.

\section{The case study of Lupaso Telecentre}

The project set out to examine factors influencing the acceptance and use of telecentres in Malawi by means of a case study of Lupaso Telecentre. Its research questions reflect Rogers' DOI theory:

1. What are the usage patterns of the Lupaso Telecentre?

2. How relevant are the telecentre services to community members?

3. What factors affect the usage of the centre? For example:

How easy/complex are the services to use?

Who influences the use of the telecentres?

Where did the users hear about the telecentre?

4. What challenges do telecentres and their users face?

4. Mwandosya, S. 2013. Personal communication, 15 September 2013

5. Ibid 
The questions were answered by means of a case study using a mix of data gathering methods. Continuous observation was conducted over two weeks, with field notes and photographs recording the observations. A questionnaire survey was conducted of 130 users, comprising almost all of the visitors to the centre during the two-week data collection period, excluding those visiting for the sake of watching sport on television. The questionnaire, piloted in a telecentre in Cape Town and translated into the local language, contained questions on demographics, use of services, perceptions of the relevance of the telecentre to the community, factors that influence respondents' use of the telecentre, and their challenges when accessing services. Its questions thus reflect DOI theory. Furthermore, interviews were conducted with key informants, including the telecentre manager, the customer care manager, the librarian, the chairman of the LTLMC, and MACRA staff. The aim was to obtain their views on the usage patterns observed by the researcher and the challenges that the telecentre faces. In keeping with the tenets of informed consent, all participants were presented with an explanatory letter and a consent form to sign. The interviewees, though not named in this report, were not assured of confidentiality because it would be important to differentiate some points based on their position as key informants. In the course of the study, certain documents and records were analysed, including receipt books, Lupaso Telecentre's constitution, the Memorandum of Understanding between the Telecentre, MACRA and Karonga District Council, and the Telecentre's attendance book.

The study's limitations have to be acknowledged upfront. The questionnaire data refer only to people visiting the telecentre; limited resources did not allow a wider lens. The findings arise from respondents' and interviewees' views. Since the aim was not to assess the impact of the telecentre on the community, no attempt was made to find further evidence for their views in other sources outside the centre.

\section{Summary and analysis of findings}

The data collected through the user questionnaire were analysed using the Statistical Package for the Social Sciences and Microsoft Excel. The qualitative data were analysed using the standard techniques of qualitative data analysis as outlined by Braun and Clarke (2006). The interviews were transcribed and then tabulated by units of meaning or themes that emerged across the interview questions. Triangulation of data across the study's components was conducted in order to confirm tentative findings. At times, data from one component, such as the observations, led to questions to be followed up in another component. The findings in this section are arranged by four themes: usage patterns, relevance of the services, factors influencing the use of services, and challenges to adoption.

\subsection{Usage patterns}

This section examines who uses the telecentre, what its users use it for, how often they use it, as well as their perceptions of why it might not be used to its full capacity.

\subsubsection{Demographics of user respondents}

In summarising the questionnaire responses, it was found that:

- $\quad$ The income levels of the telecentre users are low, with 65.6\% earning below $\mathrm{K} 5,000$ (\$10) per month.

- The biggest user groups are farmers (54\%) and small business owners (19\%). Other respondents included eleven students, ten teachers, two agricultural extension development officers, two security guards, one child protection worker and one priest.

- Unlike some findings in the literature, educational levels are not high. Only six of the 130 respondents have a postschool qualification. Moreover, there is a marked difference between male and female respondents at Junior Certificate of Education and Malawi School Certificate of Education levels.

- The age range is from thirteen to seventy years, with the the bulk of respondents $(80.3 \%)$ falling between thirteen and thirty-five years;

- $\quad$ A high proportion (73\%) of the respondents are male.

- The home language of the majority of respondents (86.8\%) is Nkhonde - a minority language nationally.

- The majority, $102(81.6 \%)$, live within four kilometres of the telecentre.

In his interview, the customer care manager confirmed the dominance of youth in their twenties. It seems that older people mostly come to the telecentre for meetings. In this extract, the manager links the use of ICTs to planning for the future, claiming that the older people in the community have no desire to change their way of life:

\footnotetext{
... You find that the elderly are married; they don't have that vision of going somewhere else; they are just around. So, they are just saying, "where can I go with knowledge because I am already older and I will not go anywhere? I will just be farming here and having life go on with my family". It's only the youths [who] have the vision, living with new technologies and willing to [change].
}

Fieldnotes throughout the two-week period confirm male dominance. The low usage of the telecentre by women might be connected to the low educational levels among women in Malawi, which were alluded to earlier. A comment by the LTLMC Chairman supports this possible explanation: 
It goes back to my first point: literacy rate. For women, munomo (here), the majority of women are those who haven't gone to school ... Another factor is that young girls who are at school ... drop out from school because of early marriages and such nature. It's also a hindrance.

\subsubsection{Frequently used services}

Users were asked to indicate the telecentre services that they had used over the past month. The literature suggests that frequently-used services tend to be those offered for free, those not available elsewhere, and those that cannot be accessed at home (Kirkman et al. 2002). Table 1 shows that the top three services used by individuals in the Lupaso Telecentre in the month preceding the survey are photocopying, borrowing books from the library, and printing. The receipt books confirm that photocopying facilities are heavily used, with the many schools in the community printing and photocopying examination papers. The receipts show that hiring of the hall by organisations generates the secondhighest income after photocopying.

Table 1 Services accessed in the month prior to the survey from most used to least $(\mathrm{N}=130)$

\begin{tabular}{lcc}
\hline Service & Responses & Percentage of respondents \\
\hline Photocopying & 84 & $64.6 \%$ \\
Borrowing books in the library & 61 & $46.9 \%$ \\
Printing & 49 & $37.7 \%$ \\
Reading newspapers and magazines in the library & 48 & $36.9 \%$ \\
Binding & 41 & $31.5 \%$ \\
Other services & 29 & $22.3 \%$ \\
Computer and information tutorials & 28 & $21.5 \%$ \\
Lamination & 23 & $17.7 \%$ \\
Finding information on the internet & 21 & $16.2 \%$ \\
Facebook and other social networking & 20 & $15.4 \%$ \\
Email & 18 & $13.8 \%$ \\
Faxing & 11 & $8.5 \%$ \\
Scanning & 9 & $6.9 \%$ \\
\hline
\end{tabular}

Note that "other services" included services being offered in the tuckshop.

Responses to a later question, summarised in Table 2, give a closer analysis of the diverse ways in which people use the telecentre. Its value as a meeting place and as an access point for information is clear.

Table 2 Purposes for accessing telecentre services $(\mathrm{N}=130)$

\begin{tabular}{lcc}
\hline Purpose & Responses & Percentage of respondents \\
\hline Leisure and entertainment (e.g. watching videos and playing games) & 68 & $52.3 \%$ \\
Meeting friends coming to the telecentre & 55 & $42.3 \%$ \\
Looking for jobs in newspaper in the library & 47 & $36.2 \%$ \\
Conducting discussions and debates with people in my community & 39 & $30 \%$ \\
Accessing government services online & 38 & $29.2 \%$ \\
Communicating with relatives, colleagues and friends online & 37 & $28.5 \%$ \\
Meeting people (e.g. friends) online & 32 & $24.6 \%$ \\
Finding information on marketing techniques & 30 & $23.1 \%$ \\
Choosing a place to study (e.g. colleges or universities) & 29 & 22.3 \\
Looking for jobs online & 29 & $22.3 \%$ \\
Finding health information (e.g. Malaria prevention) & 24 & $18.5 \%$ \\
Finding information on prices of farm produce (e.g. rice and maize) & 21 & $16.2 \%$ \\
Engaging with leaders in my village & 20 & $15.4 \%$ \\
Engaging with the government leaders at national level & 16 & $12.2 \%$ \\
Other purposes & 9 & $7 \%$ \\
Banking services online & 7 & $5.4 \%$ \\
\hline
\end{tabular}


Table 2, together with the analysis of the telecentre's receipt books, suggests that ICT services, like social media and email, are underused. Given the central mission of telecentres to provide access to ICTs in under-served areas, respondents who reported that they had not used the ICTs in the centre in the past month were presented with four possible reasons. Their responses are summarised in Figure 1. According to the figure, the main reasons for not using the ICTs are their complexity and respondents' lack of ICT skills.

Figure 1 Reasons why ICTs in Lupaso Telecentre are not widely used $(\mathrm{N}=86)$

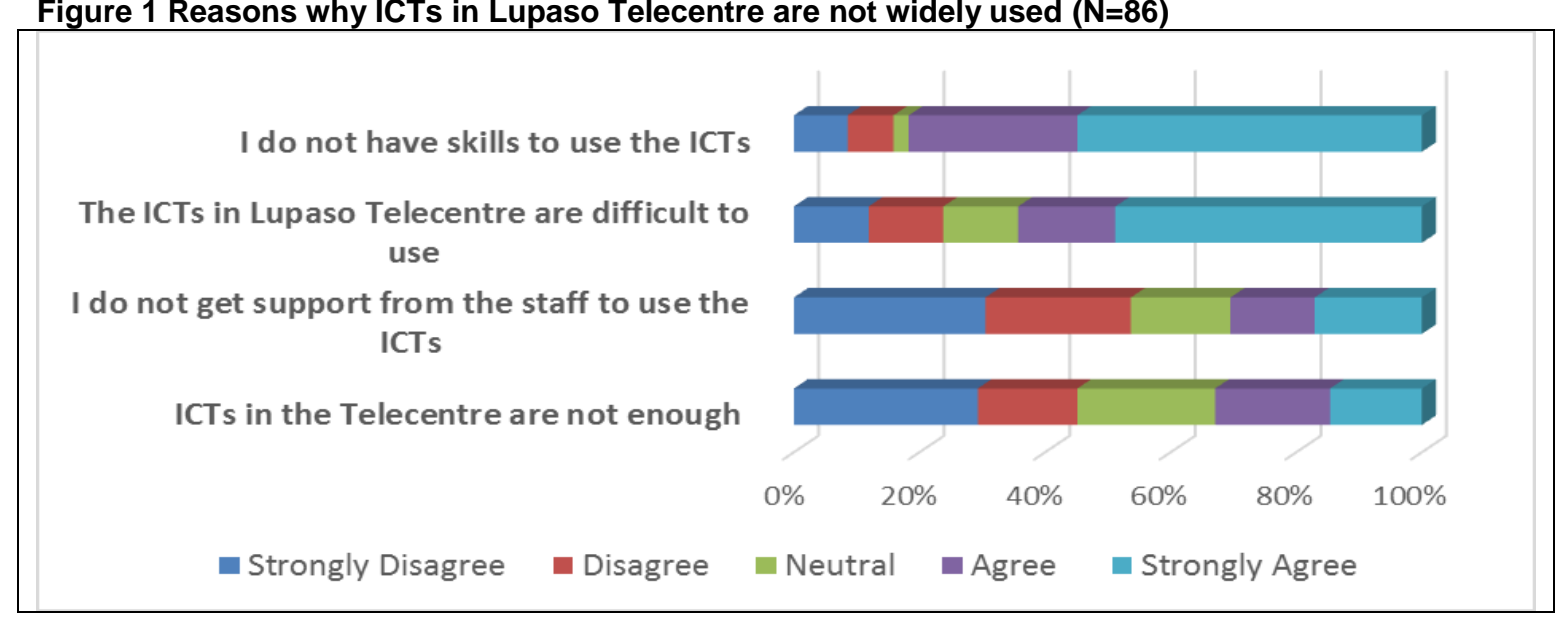

More insight might be gained from the responses to the questions on length of use and frequency. When asked to indicate how long they had been using the telecentre, almost $47.7 \%$ indicated that they had been using the telecentre since its inception; $23.1 \%$ had used the telecentre for a year. Good news for the centre is that $13.1 \%$ of the respondents reported that they joined up in the last month. However, it would be interesting to know how many will continue to use it. A scale of seven was used to determine how often users visit the telecentre. Figure 2 reveals that $58 \%$ visit at least once a week. However, $37(28 \%)$ visit "rarely" as evident in Figure 2. Their answers to the question about why they visit only rarely, summarised in Table 3, lend support to the earlier comment on Figure 1. The most common reason by far is difficulty in using its services. Most of the responses under "other" refer to lack of time because of busy farming or school commitments. Some other reasons include lack of income and having nothing to do at the telecentre.

Figure 2 Frequency of visit $(\mathrm{N}=130)$

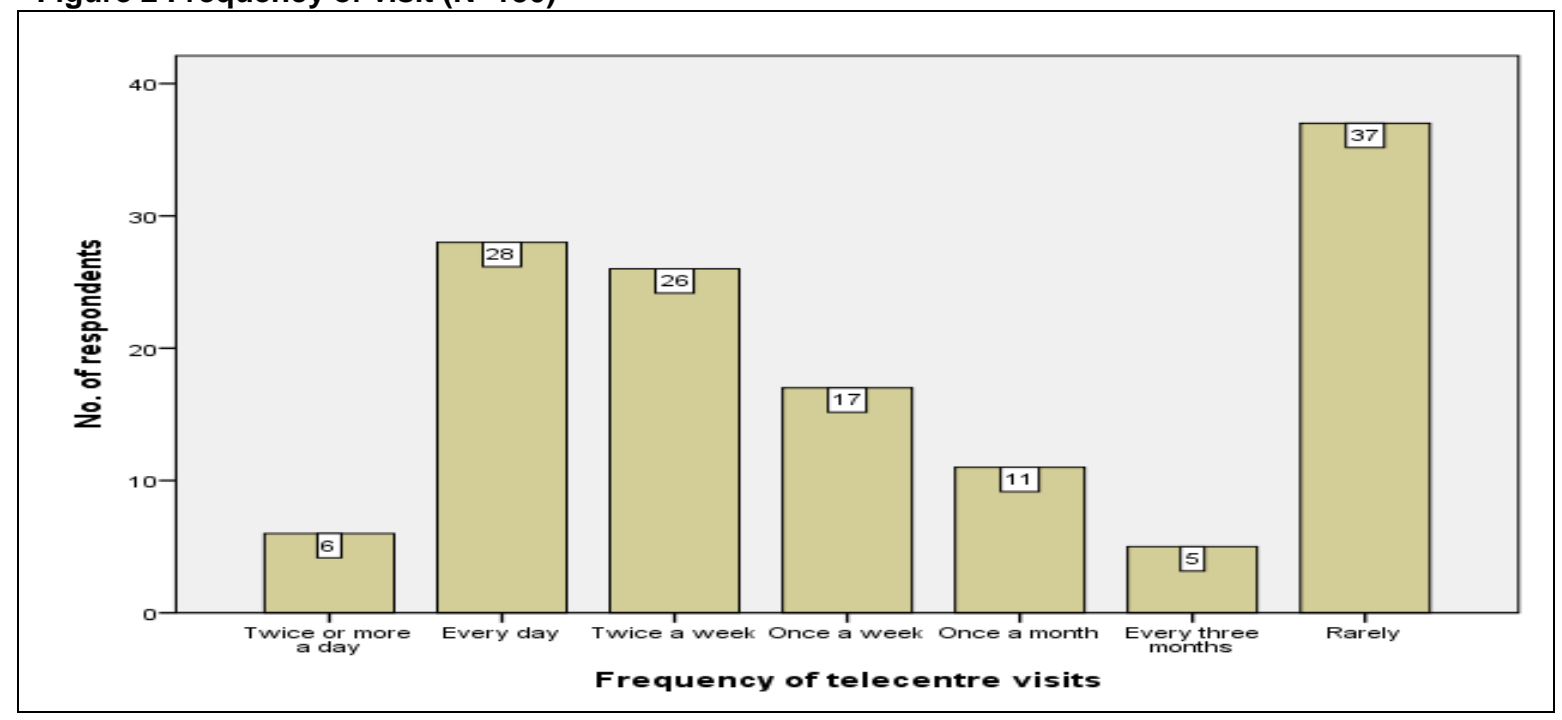

Table 3 The reasons some users visit Lupaso Telecentre "rarely" ( $\mathrm{N}=37)$

\begin{tabular}{lcc}
\hline Reason & Number & Percentage of respondents \\
\hline I find it difficult to use some services & 27 & $73 \%$ \\
Other (specify) & 11 & $29.7 \%$ \\
I get the same services at a different place at lower cost & 9 & $24.3 \%$ \\
The Telecentre does not satisfy my information needs & 7 & $19 \%$ \\
The Telecentre is too far from home & 7 & $19 \%$ \\
The services at the Telecentre are not good & 4 & $10.8 \%$ \\
\hline
\end{tabular}


The information on visitor numbers obtained through observation and the visitors' signing-in book confirms the questionnaire data that suggest the centre is not used to its full capacity. Observations over the two weeks confirmed that the ICTs often lie unused. An average of twenty different people came into the centre every day in the case study period, with the two busiest days being those of a popular football match on television and a meeting in the hall for people living with disabilities. These figures, together with those on the under-use of the ICT facilities, raise questions such as what the telecentre management is doing to attract more users from the surrounding community and how relevant the centre is to the needs of the community.

\subsection{Relevance of Lupaso Telecentre to its community}

Respondents' views on the benefits of the telecentre's and their satisfaction with its services throw light on the question of its relevance to the needs of the surrounding community. The interviews with the management of the telecentre add further insights.

\subsubsection{Benefits of Lupaso Telecentre}

Users were asked about the importance of Lupaso Telecentre in their lives. In reply to a simple yes/no question, 123 $(94.6 \%)$ of the respondents agreed that the telecentre is an important part of their lives. A follow-up open-ended question asked them to identify the benefits they have received from it. Table 4 provides an analysis of the themes or units of meaning in the responses, with selected quotations in support of each. The table shows that the telecentre is perceived as playing a big role in contributing to respondents' personal development and financial situation.

Table 4 Personal benefits of Lupaso Telecentre

\begin{tabular}{|c|c|}
\hline Units of Meaning & Examples of Responses (with Questionnaire Number (QR) \\
\hline Improving skills \& knowledge & $\begin{array}{l}\text { "Acquiring skills. I have been taught computer lessons, for example, using the internet" } \\
\text { (QR2) } \\
\text { "Increasing knowledge when reading books" (QR38) }\end{array}$ \\
\hline $\begin{array}{l}\text { Offering cheaper services and being closer than the } \\
\text { alternatives }\end{array}$ & $\begin{array}{l}\text { "Cheaper services like printing and photocopying than going to town" } \\
\text { "Saving time because it's convenient" (QR23) }\end{array}$ \\
\hline Improved financial position & "Expanded business" (QR27) \\
\hline Finding employment & $\begin{array}{l}\text { "Finding employment" (QR46) } \\
\text { "It has employed my relatives" (QR129) }\end{array}$ \\
\hline Everyday information needs & $\begin{array}{l}\text { "I am able to find information needed in my life" (QR24) } \\
\text { "Because I find all that I need to assist me in my daily life" (QR67) }\end{array}$ \\
\hline Strengthening social connections & $\begin{array}{l}\text { "Getting in touch with those who are not within reach physically" (QR10) } \\
\text { "Strengthens communication with relatives on the internet" (QR98) }\end{array}$ \\
\hline
\end{tabular}

The focus widened in the next question which asked respondents to respond to three statements on possible community benefits, based on the consensus in the literature that telecentres in developing countries are important tools for socio-economic development (Soriano 2007, Bailey 2009:9). Analysis of the responses, as shown in Figure 3, shows wide agreement on the community benefits, with, for example, $96 \%$ agreeing that the telecentre has improved users' skills and knowledge

Figure 3 Community benefits of the telecentre

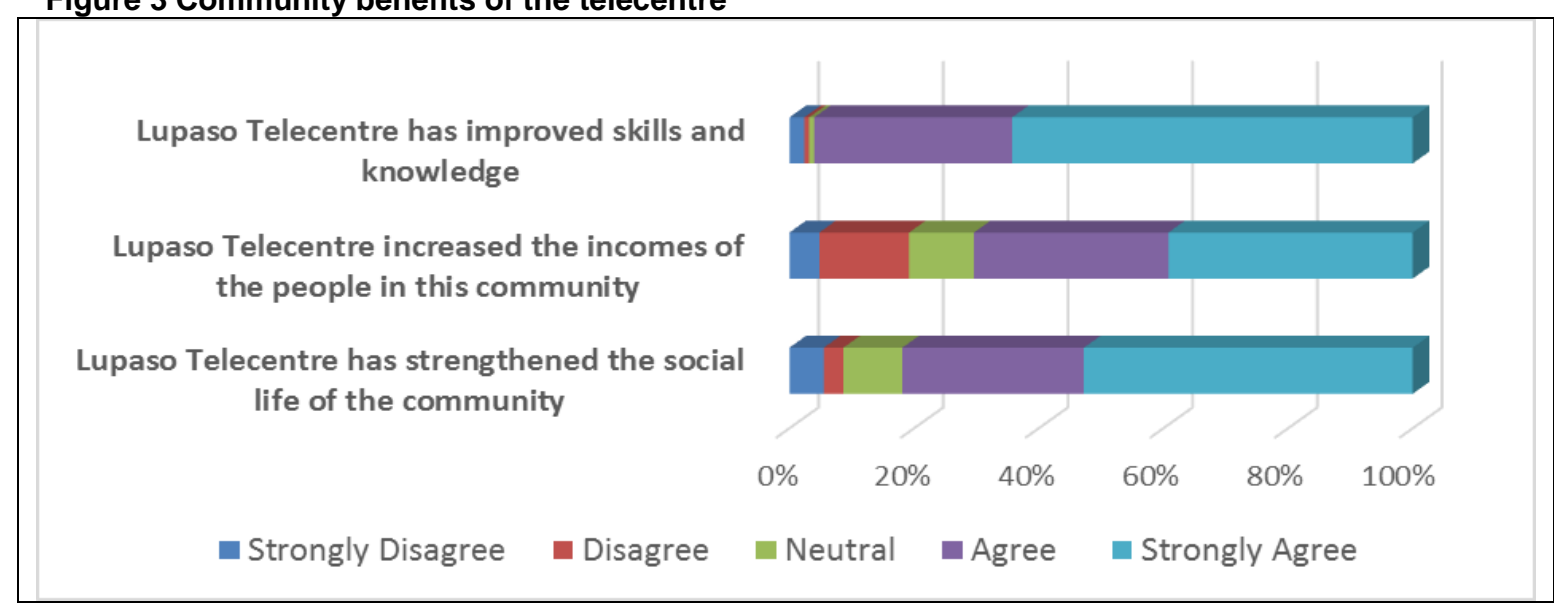

Moreover, the comments added to the questionnaires and comments in the interviews with staff give added insight into the social, financial, and human capital generated by the centre. On improving human skills, it seems the telecentre is providing computer tutorials and access to books in the library. Evidence is in the following comment made by one of the users: 
Lupaso Telecentre has improved the above-stated [for me] to gain knowledge through reading books and learning [how to use] computers (QR21)

On strengthening social connections, it appears that the telecentre is achieving this by enabling users to develop friendships at the telecentre and through provision of space which is used for debates and discussions. Observation revealed that a good number of users were coming to the telecentre to visit friends. The following comments by some users and staff lend support to this statement:

I meet my friends here (QR5)

People conduct discussions and debates at this telecentre (QR90)

People interact especially when they are watching soccer (Telecentre Manager)

People know each other at telecentres (Customer Care Manager)

The telecentre is increasing the income of its community members through the creation of job opportunities within the telecentre, although only on a small scale since only a few people work for the telecentre. According to several respondents, the telecentre is enabling people to find jobs as it allows them to acquire computer skills, and supports local farmers with its provision of information on the markets. Examples of their comments are:

It is helping people find jobs (QR32)

Some people have found employment at those telecentres. We were spending more transport expenses going to town [to find jobs], but not [any longer] (QR31)

People are [benefiting], because of the source of information and easy communication with the buyers (QR18)

The Telecentre Manager, in the extract below, agreed that the telecentre is increasing the income of people in the community:

Some of us ...were not working, but [now] we are working; we are employed just because of this telecentre ... And there were some who could not get employed because of a lack of computer skills, but, after they were trained here, they [were] employed.

\subsubsection{User satisfaction with telecentre services}

According to the results shown in Figure 4 below, it seems that the telecentre meets its users' needs, with $108(85 \%)$ of the respondents claiming to be "satisfied" with its service.

Figure 4 Users' level of satisfaction with Lupaso Telecentre services ( $N=127)$

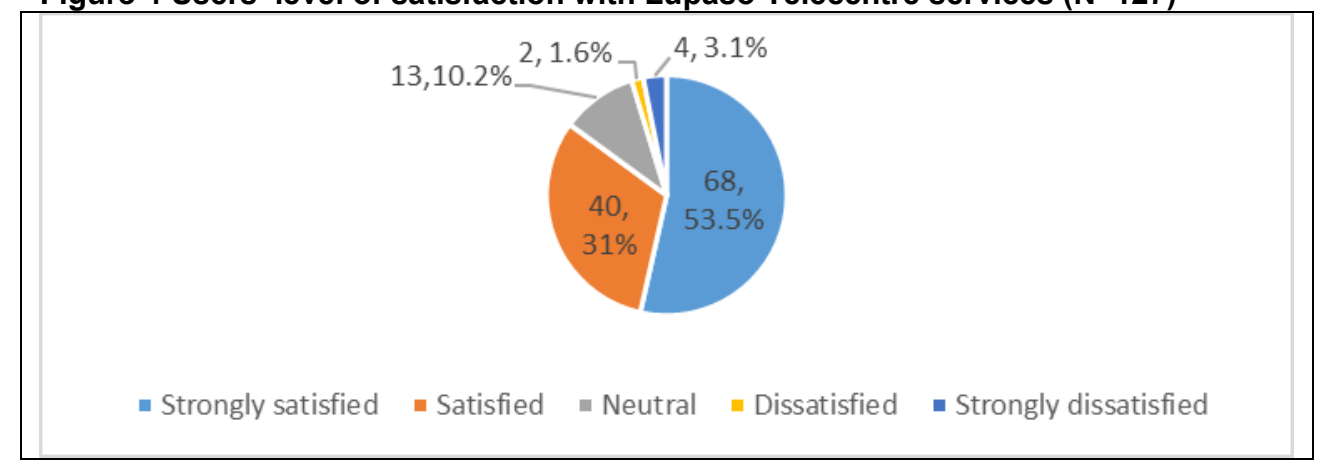

Respondents were then asked to give reasons for their level of satisfaction. Most of the responses echoed those from the earlier questions on the benefits that the telecentre is bringing to the community and to respondents personally. For example:

Receiving ICT services nearby, cheaply and faster (QR31)

People have gained experience in using technologies (QR51)

Has increased our income (QR67) 
Most of the services have matched the needs of the community (QR82)

The Telecentre Manager supported the perceptions of the relative affordability of the telecentre's services, adding the intriguing information that the centre only charges television viewers who visit for a football match:

We have so many users ... who come and watch some TV programmes. ... The reason is because most of the time, we don't charge them [for use of the television]. We only charge them during football. For instance, when Malawi is [playing against] other nations, we charge them ... And even if we charge them ..., we are cheaper than other competitors.

\subsection{Factors influencing the use of the telecentre}

This section examines the factors that influence the use of Lupaso Telecentre, relying on the views of key informants as well as the data gathered in the questionnaires. The discussion is informed by the factors that, according to Rogers' DOI theory, might affect the adoption of the telecentre by the community, namely: how its services are communicated; the social system within which it operates; the visibility of its benefits; its relative advantages over other services; its complexity; and its compatibility with its potential users' needs.

As shown in Table 5, the majority of respondents $(70.2 \%)$ indicated that they had heard about the telecentre by word of mouth.

Table 5 How did you hear about Lupaso Telecentre? $(\mathrm{N}=124)$

\begin{tabular}{lcc}
\hline & Number & Percentage \\
\hline I heard from people e.g. friends, parents, leaders & 87 & $70 \%$ \\
I heard from the media e.g. radio, television & 33 & $27 \%$ \\
Other (specify) & 4 & $3 \%$ \\
Total & $\mathbf{1 2 4}$ & $\mathbf{1 0 0} \%$ \\
\hline
\end{tabular}

Views on whether the telecentre has reached its maximum usage are divided evenly. Those who claimed that it has not, were asked to explain their views. The analysis of the replies is presented in Table 6 . Some relate to the key influencing factors in Rogers' model, for example, perceptions that people lack the necessary skills and that it does not meet some of the key needs of community members, like bricklaying classes. More criticism of the centre appears in this section than in earlier sections of the questionnaire - for example, on the unhelpfulness of the telecentre's staff and the unaffordability of its services.

Table 6 Reasons why some community members do not use the telecentre $(\mathrm{N}=60)$

\begin{tabular}{ll}
\hline Unit of meaning & Selected quotations \\
\hline Complexity, lack of IT skills & "Lack of skills and knowledge of using ICTs" (QR1) \\
& "People do not know how to find information on the internet" (QR45) \\
"People are socially backward in terms of technology. Hence few people, for example, & students, are able to use it" (QR66) \\
"Most people are illiterate so they think using telecentre needs an education. Therefore, \\
they need civic education" (QR2) \\
"Beckuse they don't know the importance of the telecentre and ... because of ignorance" \\
telecentre's purpose \\
(QR16) \\
"Unavailability of some services like production of ID photos which makes some members \\
go to Karonga town" \\
$\begin{array}{l}\text { "Some people do not use Lupaso Telecentre because some other services needed, like } \\
\text { brick laying, carpentry and joinery, are not offered" (QR109) }\end{array}$ \\
"Staff are lazy, they do not work to please people's needs" (QR12) \\
"People are now getting bored with what the staff are doing" \\
"Lack of money because other people cannot afford to pay to use computers. They wish to, \\
but have empty pockets" (QR92) \\
"Low income levels of people" \\
"Some live far from the telecentre" (QR117)
\end{tabular}

The DOI model makes much of the social influences on potential adopters of an innovation. Figure 5 below presents responses to nine Likert statements probing the influence of their social system.

It is apparent that respondents agreed that the surrounding community supports the telecentre. A possible divergence in the perspectives of the Telecentre Manager is noteworthy. The influence of community leaders is not the strongest factor in Figure 5, but to the manager, the support of the local chiefs is paramount, as shown in this extract: 
It's important to use chiefs because they are the ones who help us to mobilise their subjects ... when the chief says something here, it carries more weight than us. They trust the chiefs more than any other. ... In the past, when we were starting out, we [didn't] have many customers on computer tutorials, but [after] we went to local chief to tell [him] the importance of it ... we have seen a change [in tutorial numbers].

Figure 5 Aspects of the surrounding social system that influence usage $(\mathrm{N}=121)$

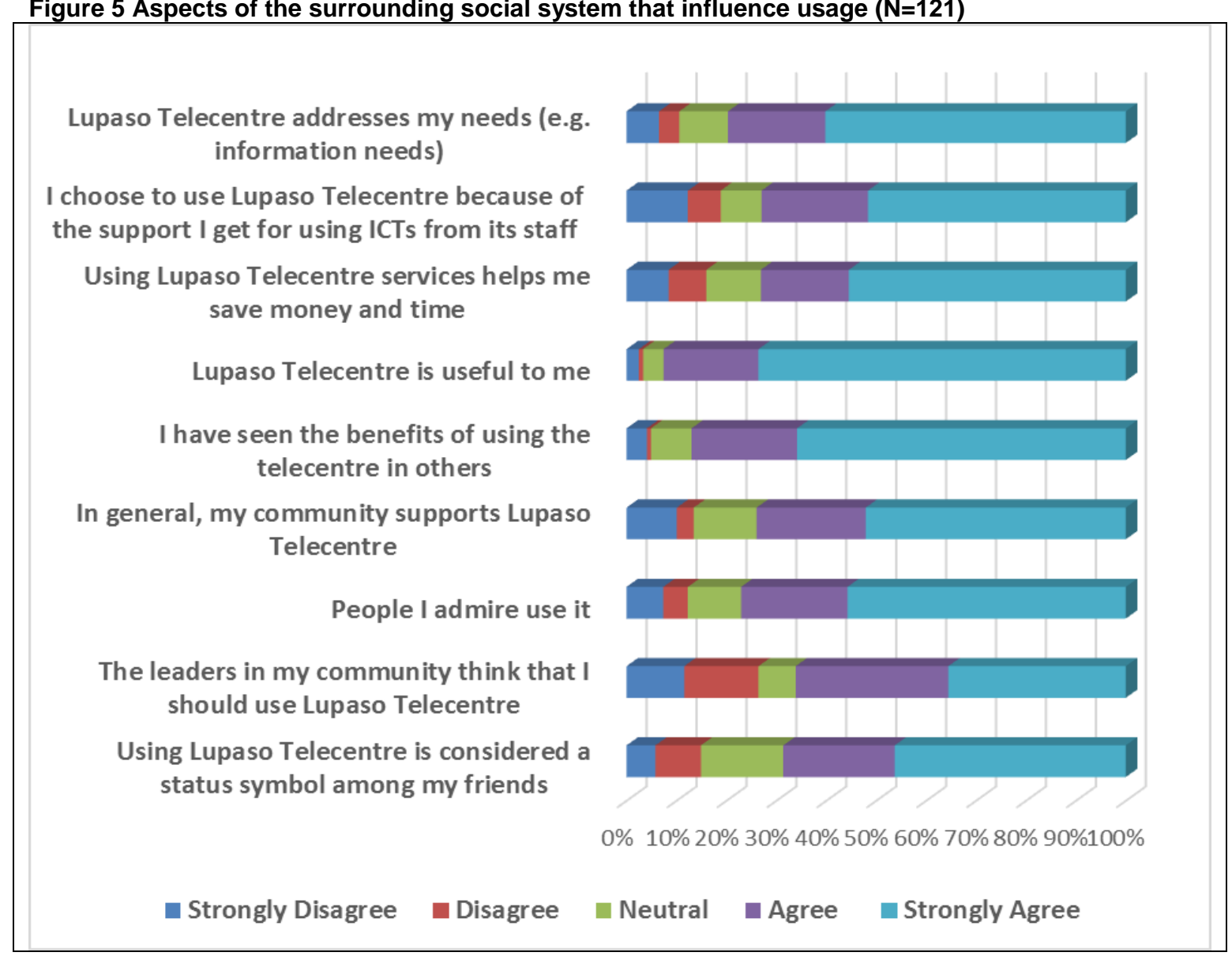

$\mathrm{DOI}$ argues the importance of the visibility of the benefits of an innovation. As Figure 5 shows, there is a high level of agreement (87\%) among the respondents to the statement, "I have seen the benefits of using the telecentre in others". These results are in line with the results presented earlier on the influence of word of mouth. Figure 5's finding that $73 \%$ of respondents use the centre "because of the support I get for using ICTs from its staff" has to be compared to some findings, reported earlier, on the difficulties in using the ICTs and the lack of support from staff. In the case study period, staff members were often observed assisting in the computer room. Perhaps, it is rather that the help available is not widely advertised.

\subsection{Challenges to use of the centre}

Table 7 below summarises the responses to a list of possible problems that confront users when using the telecentre.

Again, questions over the capacity of the community to make the most of the telecentre's ICTs come to the fore. The high number of responses about the lack of information in the dominant local language, Nkhonde, is noteworthy. The information sources in the telecentre's library are almost all in English, Malawi's official language.

The most common problem stated by those who ticked the "other" option was frequent electricity blackouts. The researcher's field notes indeed indicate that, during the two-week data collection period, there were four days with blackouts. Moreover, at times, some services were not available because there was no staff or because supplies such as toner for the printer had run out. Interviews with the telecentre's management and other key informants explored these challenges and highlighted some of the underlying factors, such as:

- the unreliable national power supplier. According to the MACRA staff member interviewed, this is a common problem across its telecentres;

- bureaucratic delays. At local level, whenever the telecentre runs out of something, the telecentre staff have to consult the management committee which can be slow to approve the request. At national level, MACRA, which supports the telecentre, sometimes delays this kind of support; and, 
- the lack of expertise within the telecentre. The Telecentre Manager explained that equipment faults are reported to MACRA which is often slow to send a technician to see to repairs.

Table 7 Challenges in accessing telecentre services $(\mathrm{N}=130)$

\begin{tabular}{lcc}
\hline & Number & Percentage of respondents \\
\hline Lack of internet searching skills & 67 & $52 \%$ \\
High costs for some services & 63 & $48 \%$ \\
Lack of information in local language & 63 & $48 \%$ \\
Inadequate physical facilities & 55 & $42 \%$ \\
Lack of support when using the telecentre & 27 & $21 \%$ \\
Lack of privacy when accessing information on the internet & 24 & $18 \%$ \\
Shortage of opening hours & 20 & $15 \%$ \\
Other (specify) & 18 & $14 \%$ \\
It is too crowded & 17 & $13 \%$ \\
\hline
\end{tabular}

\section{Conclusions}

The study investigated the factors influencing the use of multipurpose telecentres and their services in Malawi by targeting one telecentre, Lupaso Community Telecentre. The main themes explored in this study include access patterns, relevance of telecentres to communities, and factors influencing their adoption. It can be concluded that Lupaso Telecentre, despite its low and uneven usage, has the potential of transforming lives. Its users agreed on its benefits in improving the region's human, financial and social capital. Clearly, it is a social meeting place and most of its users are satisfied with the services they make use of. The study has shown that Rogers' DOI model provides a useful framework for examining a telecentre. DOI has been able to explain most of Lupaso Telecentre adoption decisions and to provide insight into its shortcomings. Thus, factors like perceptions of relative advantage, personal and social value, and complexity clearly influence adoption decisions. There was no attempt to poll non-users, but even within their general satisfaction, current users showed awareness of the centre's limitations. Its accessibility is limited by, for example, its restricted hours, unreliable power supply, unaffordability, lack of local content, and its inadequate support and training programmes. Other management challenges include bureaucratic delays and poor staff attitudes.

Perhaps the most surprising finding is that the ICTs are not its chief attraction - even though there are no other public access computing facilities in the area. Several questions arise from the clear under-use of the ICTs and the low enrolment for the ICT tutorials:

- Are the ICTs relevant? What use are they to the community which comprises mostly small-scale farmers and fishermen?

- Given the consensus on the prevailing lack of capacity to cope with the complexity of the ICTs, is the support given to novices adequate?

- Given the contradictory findings on the levels of support available in the telecentre, how do the telecentre staff and their clients see the educational role of the centre?

\section{Recommendations}

These questions might bring to mind the arguments about the relative advantages of the various models of public access computing facilities that were referred to in the introduction. Mathiesen (2008: 16), in arguing for public libraries as "Iynchpin institutions" in providing for the basic human right of access to information, points out that public libraries offer digital and information literacy education programmes which empower people to use information to make better lives for themselves. The study by the HSRC, mentioned earlier, of ICT access across South Africa, provides support for Mathiesen's arguments, concluding that libraries add value to their ICT facilities by means of their educational programmes which teach "information management skills" (Tlabela et al. 2007: 100). The evolving South African Thusong Centres, which combine public libraries, telecentres and government information services, might well offer a promising model to enrich the telecentre model in Malawi (Library \& Information Services (LIS) Transformation Charter 2014: 53).

The study's findings suggest the following recommendations for Lupaso Telecentre staff, LTLMC and MACRA. Hopefully, these will also be applicable to other telecentres in Malawi and other developing countries.

- In order to incorporate all groups in the community, telecentre managers and operators should be providing various programmes targeting different groups of people (Sharma 2008). For example, provision of radio programmes on farming would encourage elderly people to visit the telecentre.

- Conducting regular community needs assessments will help telecentre services and programmes reflect what people need from the telecentre.

- Education is needed to remove misconceptions that telecentres are only intended for the educated. However, literacy classes should also be introduced because many services require the ability to read and write. 
- $\quad$ MACRA and the telecentre management should invest in an alternative power supply, for example, a generator.

- Telecentre management should collaborate with organisations such as academic institutions in order to create localised content, partly to solve the problem of lack of local content.

- $\quad$ Technical expertise should be available within the telecentres. This would mean employing another staff member as a technician or capacity-building among the existing staff.

- $\quad$ MACRA should train telecentre staff in customer care.

\section{References}

Abdulwahab, L. and Zulkhairi M. D. 2011. Effectiveness of telecentre using a model of Unified Theory of Acceptance and Use of Technology (UTAUT): structural equation modelling approach. Journal of Emerging Trends in Computing and Information Sciences, 2(9): 402-412.

Attwood, H., Diga, K., Braathen, E. and May, J. 2013. Telecentre functionality in South Africa: re-enabling the community ICT access environment. The Journal of Community Informatics, 9(4). [Online]. http://cijournal.net/index.php/ciej/article/view/970/1060 (27 June 2016).

Bailey, A. 2009. Issues affecting the social sustainability of telecentres in developing contexts: a field study of sixteen telecentres in Jamaica. The Electronic Journal of Information Systems in Developing Countries, 36(4): 1-18.

Braun, V. and Clarke V. 2006. Using thematic analysis in psychology. Qualitative Research in Psychology, 3(2): 77-101.

Chigalu, S. 2006. ICT for Sustainable Rural Development Telecentre Project: feasibility study findings report: challenges and opportunities on rural telecentre development in Malawi. [Presentation]. Ryalls Hotel, Blantyre, Malawi. 29 May. [Online]. http://www.ictmalawi.com/presentations/ISR (20 May 2013).

Chigona, W., Lekwane, O., Westcott, K. and Chigona, A. 2011. Uses, benefits and challenges of public access points in the face of growth of mobile technology. The Electronic Journal of Information Systems in Developing Countries, 49(5): 1-14.

Chigona, W. and Licker, P. 2008. Using Diffusion of Innovations framework to explain communal computing facilities adoption among the urban poor. Information Technologies \& International Development, 4(3): 57-73.

Chilimo, W.L. 2008. Information and communication technologies and sustainable livelihoods: a case of selected rural areas of Tanzania. PhD thesis. University of KwaZulu-Natal. [Online]. http://researchspace.ukzn.ac.za/xmlui/handle/10413/188 (5 July 2013).

Department of Immigration. Republic of Malawi. n.d. List of prescribed languages. [Online]. http://www.immigration.gov.mw/list-of-languages-in-malawi.html (2 April 2016).

Etta, F. E. and Parvyn-Wamahiu, S. Eds. 2003. Information and communication technologies for development. Vol. 1: the experience with community telecentre. Ottawa: International Development Research Centre.

Government Communication and Information Systems. 2013. The Government Development Communication Initiative: a response to democratic communication and citizen participation in South Africa. [Online]. http://www.thusong.gov.za/documents/policy_legal/gdc.htm (5 March 2016).

Gómez R., Hunt, P. and Lamoureux, B. 1999. Telecentre evaluation and research: a global perspective. In Telecentre evaluation and research: a global perspective. Report of an international meeting on telecentre evaluation. R. Gómez and P. Hunt, Eds. Ottawa: International Development Research Centre. 13-27.

Harris, R. 2001. Telecentres in rural Asia: towards a success model. Europe, 40(23): 71-111. [Online]. http://unpan1.un.org/intradoc/groups/public/documents/apcity/unpan006304.pdf (3 July 2013).

Haseloff, A. M. 2005. Cybercafés and their potential as community development tools in India. The Journal of Community Informatics, 1(3). [Online]. http://www.ci-journal.net/index.php/ciej/article/view/226/182 (04 March 2014).

Huerta, E. and Sandoval-Almazán, R. 2007. Digital literacy: problems faced by telecenter users in Mexico. Information Technology for Development, 13(3): 217-232.

Human Development Report. 2015. Human Development Report 2015: Work for human development. New York: United Nations Development Programme.

Isaacs, S. 2007. Survey of ICT and education in Africa: Malawi country report. [Online]. http://www.infodev.org/infodeviles/resource/InfodevDocuments_414.pdf (10 July 2015).

Kirkman, G. S., Cornelius, P., Sachs, J. and Schwab, K. 2002. Global information technology report, 2001-2002. New York: Oxford University Press.

Kumar, R. and Best, M.L. 2007. Social impact and diffusion of telecentre use: a study from the Sustainable Access in Rural India project. The Journal of Community Informatics, 2(3). [Online]. http://cijournal.net/index.php/ciej/article/viewArticle/328 (1 April 2016).

Lesame, Z. 2006. Telecentres and sustainable community development in South Africa. TPRC. [Online]. http://ssrn.com/abstract=2120265 (5 March 2014).

Nkondo, M., Brown, A., Dick, A., Hart, G., Molawa, S., Nassimbeni, M., Seleti, Y. and Teffo, L.J. 2014. The Library and Information Services (LIS) Transformation Charter. Pretoria: Department of Arts and Culture (DAC) and the National Council for Library and Information Services (NCLIS). [Online]. http://www.nlsa.ac.za/Downloads_01/2014_Final_LIS_Transformation_Charter.pdf (24 October 2015).

Malawi. 2003. Malawi Information and Communications Téchnology (ICT) $\bar{P}$ olicy. [Online]. http://www.macra.org.mw/downloads/malawi_ict_policy.pdf (15 March 2013). 
Malawi. 2012. Integrated household survey 2010-2011: household socio-economic characteristics report. [Online]. http://www.nsomalawi.mw/images/stories/data_on_line/economics/ihs/IHS3/IHS3_Report.pdf (22 September 2013).

Mark, G. and Poltrock, S. 2001. Diffusion of a collaborative technology across distance. Proceedings of the 2001 International ACM SIGGROUP Conference on Supporting Group Work. 30 September-3 October 2001. Boulder, CO.: ACM Press. 232-241. [Online]. http://dl.acm.org/citation.cfm?id=500321 (5 June 2013).

Mathiesen, K. 2008. Access to information as a human right. [Online]. http://dx.doi.org/10.2139/ssrn.1264666 (14 October 2014).

Mtega, W. and Malekani, A. 2009. Analyzing the usage patterns and challenges of telecentres among rural communities: experience from four selected telecenters in Tanzania. International Journal of Education and Development Using ICT, 5(2): 68-87.

Malawi VP opens K80M multipurpose telecentre in Karonga. 2012. Nyasa Times. 13 September. [Online]. http://www.nyasatimes.com/malawi-vp-opens-k80m-multipurpose-telecentre-in-karonga/ (15 September 2013).

Nyirenda, P.B. 2014. Report \#2 on Malawi ICT sector key indicators on infrastructure and access. Regional communications infrastructure programme Malawi project. Monitoring and evaluation consultancy [Online]. http://www.nic.mw/RCIPMW-reports/Report-2-ver1.5-Malawi-ICT-Sector-Key-ICT-Indicators-on-Infrastructure2014.pdf (1 September, 2015).

Parkinson, S. and Ramirez, R., 2007. Using a sustainable livelihoods approach to assessing the impact of ICTs in development. The Journal of Community Informatics, 2(3). [Online]. http://cijournal.net/index.php/ciej/article/view/310/269 (27 May 2016).

Prado, P., Câmara, M.A. and Figueiredo, M.A.D. 2011. Evaluating ICT adoption in rural Brazil: a quantitative analysis of telecenters as agents of social change. The Journal of Community Informatics, 7(1-2): 1-25.

Rogers, E.M. 1995. Diffusion of Innovations. 4th ed. New York: The Free Press.

Roman, R. 2003. Diffusion of Innovations as a theoretical framework for telecenters. Information Technologies \& International Development, 1(2): 53-66.

Sharma, S. 2008. What brings people to the telecentres? Telecentre Foundation. 10 December. [Online]. http://community.telecentre.org/profiles/blogs/what-brings-people-to-the (20 February 2014).

Soriano, C. R. R. 2007. Exploring the ICT and rural poverty reduction link: community telecentres and rural livelihoods in Wu'an, China. The Electronic Journal of Information Systems in Developing Countries, 32. [Online]. http://www.ejisdc.org/ojs2/index.php/ejisdc/article/view/462/230 (20 April 2013).

Tlabela, K., Roodt, J., Paterson, A. and Weir-Smith, G. 2007. Mapping ICT access in South Africa. Cape Town: HSRC Press.

Twinomurinzi, H., Phahlamohlaka, J. and Byrne, E. 2012. The small group subtlety of using ICT for participatory governance: a South African experience. Government Information Quarterly, 29(2): 203-211. 